\title{
Is There a Fatherhood Wage Premium? A Cautionary Tale from Modified Male-Breadwinner Societies
}

\author{
Gabriele Mari* \\ Unrefereed manuscript. Pre-print
}

\begin{abstract}
The transition to parenthood deepens economic inequalities between women and men. In labour markets, motherhood leads to substantial wage penalties for women, whereas the wage progression of men marches on come fatherhood. Yet relatively little evidence exists on whether fatherhood grants men a wage premium or superior wages spur the transition to fatherhood instead. Also, most longitudinal studies have focused on the US, neglecting a comparative perspective that may unravel the contextual underpinnings of fatherhood wage premiums (if any).

I carry out here a comparative and longitudinal analysis of how fatherhood may affect men's wages. Micro-level mechanisms supporting the idea of a wage premium changes in men's work effort, couple specialization, and employer discrimination - are discussed in light of stability and changes in the institutional settings of two modified male-breadwinner societies, the UK and Germany. Empirical evidence in this study, however, cannot support the idea of a causal premium for men, even in such contexts. Rather, I highlight the role of previously neglected sources of selection into fatherhood, particularly on the basis of prior wage growth.
\end{abstract}

${ }^{*}$ University of Trento and Tilburg University. Note: The data from the BHPS and UKHLS used here were made available through the UK Data Archive (University of Essex, Institute for Social and Economic Research, 2018), while data from the G-SOEP were made available by the German Institute for Economic Research (DIW), Berlin, 2016. Neither the original collectors of the data nor the archive bear any responsibility for the analyses or interpretations presented here. The author wishes to thank Lynn Prince Cooke and Rossella Icardi for useful comments on a previous version of this draft. All the errors remain the author's own. 
Parenthood divides the careers of women and men in labour markets, particularly when it comes to wages. On average, the gender wage gap widens as women and men approach their late 20s and early 30s, the life-course stage of family formation. Parenthood, indeed, has been shown to result in substantial wage losses for employed women and recent studies have coherently highlighted how the price of motherhood is a key factor behind gender wage gaps in high-income countries (for a review, Ponthieux and Meurs, 2015).

What about men though? Counterpart to the wage penalty for mothers, fathers typically out-earn childless men, as highlighted by cross-sectional studies (e.g. Petersen et al., 2011). Also, the wages of men shift upwards, even if modestly so, when comparing the periods before and after the transition to fatherhood (Lundberg and Rose, 2000; Killewald, 2013). Yet, while the question of whether motherhood causally affects wages has come under intense scrutiny (e.g. Elwert and Winship, 2014), few have asked the same about fatherhood (for an exception, Loughran and Zissimopoulos, 2009). In line with recent studies disputing whether marriage causally affects men's wages (Killewald and Lundberg, 2017; Ludwig and Brüderl, 2018), I ask if data support a causal story for the link between fatherhood and wages.

Asking such a question contributes, first, to the broader issue of gender economic inequality. In the labour market, fatherhood wage premiums may further deepen the gender wage gap or make it such that, even if the mommy penalty will narrow down, the gender wage gap will endure (Petersen et al., 2014). In the household, fathers' wage boosts may on the one hand compensate for drops in household income due to the motherhood penalty (e.g. Dotti Sani, 2015). On the other though, the mix of a wage premium for fathers and a wage penalty for mothers in the market would arguably sustain a specialized yet unequal division of labour in couples, with ripple effects on the labour market behaviour of both parents, on the opportunity cost of children, and on the stability of couples themselves (e.g. Bianchi and Milkie, 2010; Cooke and Baxter, 2010).

Second, mechanisms that might generate the wage premium are of general interest to the 
understanding of how work and family intertwine in contemporary societies. Specifically, changes in work effort, couple specialization, and employer discrimination have all been called upon to explain wage premiums for fathers (Killewald and Gough, 2013; Killewald, 2013; Bygren et al., 2017). Differently, the demography of fatherhood, who becomes a father and at what stage of his life course, has largely been neglected. As a counterpoint to the mechanisms seemingly generating the premium, therefore, I consider here how multiple sources of selfselection into fatherhood may invalidate the causal story for the premium itself.

A third and last contribution lies in the study design. While previous studies have been mainly US-based, I focus here on two countries with strong male-breadwinner legacies, Germany and the UK. The inability to support a causal story for fatherhood and wages would indeed be particularly meaningful in countries that have long supported male breadwinning, both culturally and through policy. Also, recent institutional transformations in the two countries, "modifying" the original male-breadwinner model, make it possible to investigate change across cohorts in the extent and drivers of fatherhood wage premiums (if any). Throughout all my analyses, finally, I exploit recent advances in the literature on fixed-effects panel data models, the workhorse model in the field of parenthood and labour market outcomes, highlighting pitfalls and benefits of different approaches to the study of the (economic) consequences of life events (e.g. Brüderl and Ludwig, 2015; Borusyak and Jaravel, 2016; Imai and Kim, 2017).

\section{Background}

1.1. Why there could be a fatherhood premium: effort, specialization, and discrimination Wage premiums for fathers may stem out of three main channels: individual changes in work effort, couple specialization, and employer discrimination. These mechanisms may all generate fatherhood wage bonuses in labour markets, yet reviewing the mechanisms themselves - and the contexts they are embedded in - casts doubts on the leverage these explanations 
may really have.

Fatherhood may act, first, as a transforming event that pushes men to increase their effort on the job (Eggebeen and Knoester, 2001; Percheski and Wildeman, 2008), either by working longer hours or being more productive. For the US, Killewald (2013) provides indirect support for this hypothesis when she finds that men get a fatherhood premium only when married and co-residing with their biological children. Stronger ties to their children and partner, she argues, may motivate men to commit more fully to breadwinning, yet the study lacks direct measures of work effort to further support this conclusion. Also, previous studies for the US found that unmarried men, rather than married men, typically increase their working hours after the transition to fatherhood (Astone et al., 2010).

Adopting a couple perspective, rather than a purely individual one, may add nuance to the effort hypothesis. Partners may rationally allocate time/effort in paid and unpaid work to maximize the utility of the household they compose (Becker, 1981). The transition to parenthood arguably enhances this dynamic since the presence of children requires additional earnings and boosts the demand for unpaid work within the household (e.g. Vargha et al., 2017). Hence, fatherhood may propel a man to work longer hours when his earning potential exceeds that of his partner.

The implication of such a model of couple specialization is that fatherhood wage premiums should be observed in particular for those men whose partner reduces working hours or leaves paid work come parenthood. Indeed US-based studies find that married fathers, whose wives interrupt employment or cut back work hours, add extra working hours of their own and gain a wage premium (Lundberg and Rose, 2000; Killewald and Gough, 2013; Killewald, 2013). Assessing the impact of couple-level specialization on the wages of fathers is complicated, however, by the "endogeneity of family" (Lundberg, 2005). Couple formation is often a transitory event, considering that splitting and re-partnering are commonplace (Elzinga and Liefbroer, 2007). If specialization affects couple formation and stability, conditioning the 
analyses of fatherhood premiums on the presence and characteristics of a partner may induce selection bias (Elwert and Winship, 2014). For example, if couples in which women do not specialize in household production are more likely to split (e.g. Kalmijn et al., 2007; Lepinteur et al., 2016; for a review, Cooke and Baxter 2010), "surviving" couples at any given point in time may be the ones more likely to (have) specialize(d). The role of couple specialization on fathers' wages may thus be exaggerated, yet studies have neglected this point so far (e.g. Killewald and Gough, 2013).

Moving on from the behaviours of fathers and couples, wage premiums for fathers may also precipitate from employer discrimination. Employers may have a preference for fathers, rooted in the perception that fathers will be more productive, competent and/or committed than their childless counterparts (cf. Phelps, 1972; Correll et al., 2007). Despite the lack of factual productivity differences between male employees, men could be differentially treated in the workplace depending on parental status. In a lab experiment with US undergraduate students, Correll and colleagues (2007) indeed find that fathers are evaluated as more committed, would be hired more often, and would be offered higher starting salaries than childless men, holding job applicants' features equal. Yet, in the companion field experiment, differences in call-back rates between "equivalent" fathers and childless men were not detected. The same inconclusive evidence has recently emerged from a large field experiment across multiple job titles in Sweden (Bygren et al., 2017).

1.2. Contextual underpinnings of the wage trajectories of fathers in Germany and the UK Whether in previous US-based studies or in European comparisons (Killewald and Gough, 2013; O'Brien and Koslowski, 2017), contextual factors that may shape the fatherhood premium and its drivers have been overlooked (cf. Cooke, 2014). Yet one might expect that a strong male-breadwinner norm, both culturally and institutionally enforced, may foster fathers' effort allocation, couples' traditional specialization, or employer bias in favour 
of fathers. Comparing the UK and Germany, I consider here countries with strong malebreadwinner traditions, i.e. whose welfare and labour market institutions have long supported men's role as main, if not sole, providers in the family (e.g. Lewis, 1992). Both countries have now variously departed from the male breadwinner model by supporting women's employment, although especially in the form of part-time employment (e.g. Anxo et al., 2007; Fouarge et al., 2010; Trappe et al., 2015). Lately, and to a much greater extent in Germany, care rights and obligations have been expanded to fathers by the introduction of paternity and parental leave mandates (e.g. Kluve and Tamm, 2013; O'Brien and Koslowski, 2017). This transition to a "modified" male breadwnner model (e.g. Crompton, 1999) further enriches the chance to understand the contextual underpinnings of fatherhood premiums (if any) over time in the two countries.

Fatherhood may act as a transforming event and spur men's work effort particularly in contexts where male breadwinning is culturally reinforced (Townsend, 2002). Consistent with a male-breadwinner ideology (Davis and Greenstein, 2009), unfavourable attitudes towards mothers' employment - whether full-time or in general during a child's pre-school years - persist in the UK and Germany (O'Reilly et al., 2014; Dechant and Rinklake, 2016). Still, looking at change over time in a macro perspective, attitudes in both countries have shifted away from once prevalent traditionalist views that assigned to men the role of (sole) breadwinners and to women that of full-time carers and home-makers (Knight and Brinton, 2017). More to the point, investigating change over time within individual life-cycles, studies cannot ascertain whether men's attitudes towards work and family become more traditional as a result of the transition to fatherhood (for the UK: Grinza et al., 2017; Kuziemko et al., 2018).

Consistently, findings regarding fathers' working hours as a proxy for effort suggest that, even in former male-breadwinner regimes, men do not commit more fully to breadwinning after the birth of a child. Indeed, average working hours actually decline after the transition to 
fatherhood in most European countries (Bünning and Pollmann-Schult, 2016). In Germany, becoming a father prompts an increase in working hours for men born prior to 1960, but a decrease in working hours for men belonging to younger cohorts, and both changes are modest in size (1 h of paid work at most, Pollmann-Schult and Reynolds, 2017). For Britain, previous studies provide little evidence that the presence of children affects men's working hours at all (Bryan, 2007; Paull, 2008; Schober, 2013).

Nevertheless, men could still increase their work effort conditional on their partner's investment in the household, in line with a traditional mode of couple specialization. Tax policies, for example, may provide incentives for particular arrangements of paid and unpaid work between partners. Taxing partners' incomes jointly, Germany discourages married women's employment (Gustafsson, 1992; Bick and Fuchs-Schündeln, 2017) and may thereby foster traditional couple specialization. Differently, Britain switched from joint to individual taxation in 1990, further pursuing tax credit policies since the end of the 1990s with the aim of encouraging maternal labour supply (Francesconi and Van der Klaauw, 2007; Francesconi et al., 2009). Perhaps surprisingly, though, couple specialization in both the UK and Germany deviates from the Beckerian model when it comes to the transition to parenthood. While mothers indeed trade off employment hours with time spent in housework and childcare, fathers' allocation of time to either paid or unpaid work is hardly affected by parenthood regardless of their partner's behaviour (e.g. Schober, 2013; Kühhirt, 2012).

Employer bias in favour of fathers may still rest on the assumption, however justified, that men will maintain or even increase their commitment to paid work after the birth of a child. In recent years, such an assumption may have eroded because of fathers' use of paternity and parental leaves, which may signal a parallel and potentially conflicting commitment to the family sphere. In Britain, the overwhelming majority of fathers now takes time off around the birth of a child, although mostly in the form of the two-week paternity leave introduced in 2003 (O'Brien and Koslowski, 2017). In Germany, fathers have been entitled to paid parental 
leave provisions since the end of the 1980s, but fathers' uptake became substantial only after a 2007 reform instituting two months of leave reserved for fathers. According to the latest figures, more than $30 \%$ of German fathers now use parental leave provisions, typically for the statutory minimum of two months (Bünning, 2015; Kluve and Tamm, 2013). Notably, these figures for German fathers approach those of their counterparts in Sweden. Swedish fathers taking parental leave have been found to experience modest wage penalties after returning to work, a finding scholars have interpreted as evidence of adverse signalling ${ }^{1}$ (Albrecht et al., 2015, 1999). It is at best unclear, therefore, if employers may still assume a fuller commitment to work from fathers and discriminate in their favour, particularly in modern-day Germany.

\subsection{Why there might not be a fatherhood premium after all: the role of selection}

Mixed support for the mechanisms seemingly generating wage premiums for fathers, even when considering contexts in which we might expect them at work the most, prompts taking a step back. It is natural to ask whether apparent wage boosts come fatherhood are causal or rather driven by selection into fatherhood. I consider here two sources of selection: selection on prior wage levels and selection on prior wage growth. I call the first static selection, as it pertains to differences between the types of men who become fathers and those who remain childless, and the second dynamic selection, since it concerns the life-stage in which some men become fathers and others do not.

Similar to selection into marriage (for a review, Ludwig and Brüderl, 2018), static selection entails that high-earning men are, by the same token, more likely to become fathers. As Cooke and Fuller put it (2018: 783), "positive selection might account for the gross (wage) premium if the men who become fathers have unmeasured characteristics such as loyalty and commitment valued similarly by employers and potential partners". If such positive selection holds, ignoring it would lead to an overestimation of fatherhood wage premiums.

Research on what kind of men eventually become fathers, and what kind does not, is rela- 
tively under-developed (Balbo et al., 2013; Kreyenfeld and Konietzka, 2017). Across countries, highly educated men have better chances of becoming a father than do low-educated men, yet much is due to selection into union (e.g. Trimarchi and Van Bavel, 2017). If fatherhood and union formation are a compound, then one might expect the type of selection into fatherhood to overlap with that into marriage, with both of them being positive (for a review, Ludwig and Brüderl, 2018). As long as such drivers of positive selection are unobserved, cross-sectional estimates of the bonus (e.g. Cooke, 2014; Petersen et al., 2011, 2014; Cooke and Fuller, 2018) might thus suffer from selection bias due to omitted variables in the regression equation. Panel estimates, differently, can be augmented by adding individual fixed effects to curb estimates from selection on such time-invariant unobservables. Comparing the latter to cross-sectional estimates has highlighted negative selection may be at play, as panel estimate of the daddy bonus are typically bigger than their cross-sectional counterparts (Lundberg and Rose, 2000; Hodges and Budig, 2010). Yet, once again, these studies have only focused on the US. They could thus speak to the specificity of the American context where fatherhood - or at least early fatherhood - may go hand in hand with markers of earning and life-course disadvantage such as dropping out of high school or incarceration (e.g. Dariotis et al., 2011). Hence, also the direction of selection on prior wage levels is at best ambiguous, much like the effectiveness of mechanisms purportedly leading to a causal bonus discussed in the previous sections.

Yet selection could also operate through a different path. Men may select into fatherhood, depending on their wage growth rather than simply on their wage levels (Ludwig and Brüderl, 2018). The transition to parenthood may simply occur at times of fast wage growth in the career-cycle (Killewald and Lundberg, 2017). From a human capital perspective (e.g. Blackburn et al., 1993), this might be of particular relevance for men belonging to younger cohorts and who attained higher levels of education, as they typically have children later in life after considerable accumulation of experience and wages in the market (McMunn et al., 
2015; Struffolino et al., 2016).

Previous comparative studies for European countries, including the UK and Germany, have found indeed that the wages of men are growing already in the period prior to fatherhood (O’Brien and Koslowski, 2017). Yet such literature has not drawn one important implication out of this finding. If the wage spikes prior to fatherhood are comparable to the wage spikes observed after fatherhood, then speaking of a bonus sparked by fatherhood is unwarranted given the observed data pattern (e.g. Killewald and Lundberg, 2017; Ludwig and Brüderl, 2018). The tests I devise in this study, therefore, will try to detect a spike in wages occurring in the aftermath of fatherhood, once men's selection into fatherhood - based on both wage levels and on wage growth - is accounted for.

\section{Empirical approach}

\subsection{Data and samples}

I employ long-running household panel data, namely the German Socio-Economic Panel (G-SOEP v31.1, 1984-2014) and the British Household Panel (1991-2016). Both are multipurpose household surveys following the lives of a representative sample of each country's residents (Wagner et al., 2007; Taylor et al., 2010; Buck and McFall, 2011). Both datasets are augmented by fertility history files (see, respectively, Goebel, 2017; Pronzato, 2011) to recover information on the transition to fatherhood.

For the UK, I rely on all BHPS sample members. While the BHPS was temporarily discontinued in 2009, its sample started being interviewed again in 2010-11, within the framework of the UK Household Longitudinal Study (UK-HLS). My analyses thus rely on the full data available for the BHPS sample, covering, despite the gap, the period 1991-2016. For Germany I employ samples A to $\mathrm{H}$, as well as refreshment samples J and K. In the main analyses, I focus on men aged 20 to 50, working as dependent employees, with non-missing information

on their fertility history as well as on their current wage. Further, given my focus on the 
transition to fatherhood, I restrict my analyses to men that, when first observed in the panel, had no children. During the observation period then, part of this initial pool will experience the transition to fatherhood ("treated group"), while the rest will remain childless ("control group"). For some of the men in this latter group, family histories may be truncated though: they might become fathers after the last data-point in each panel or drop out of the panels prior to their transition to fatherhood. If arguments on selection hold, this subgroup of men among the controls might actually be more similar to fathers(-to-be) than to childless men, and this would in turn attenuate estimates of the fatherhood premium. Hence, to ensure that the control group does not include prospective fathers, who might be on a similar wage trajectory to that of the treated, I further limit my analysis to men who have been observed at least until age 40, thereby selecting cohorts of men born not after 1974 for Germany and not after 1976 for the UK. The cut-point at 40 is assumed to be indicative of completed fertility for men, as less than $10 \%$ of the transitions to fatherhood occurred past age forty in our final samples for both countries (see also Kleven et al., 2018).

Finally, due the requirements of one of the statistical models I will use (FEIS model, see below), I further limit my analyses to men who have been observed for at least three waves in the panel (Brüderl and Ludwig, 2015; Ludwig and Brüderl, 2018). All together, these restrictions result in a sample of 2,743 men (1,103 of which will become first-time fathers) and 35,297 person-year records for Germany, and a sample of 1,283 men (639 of which will become first-time fathers) and 15,730 person-year records for the UK.

\subsection{Fatherhood and wages: model specifications}

I start from a simple OLS specification of the wage equation,

$$
y_{i t}=\alpha+\beta C h i l d_{i t}+\gamma_{1} \text { Age }_{i t}+\gamma_{2} A g e_{i t}^{2}+\phi_{t}+\epsilon_{i t}
$$


where $y_{i t}$ is the log of real hourly wages. Hourly wages are computed dividing gross monthly pay by the amount of weekly working hours multiplied by 4.35 , the approximate number of weeks in a month. For the BHPS arm of my analysis, I sum weekly working hours and hours of overtime (Bryan and Sevilla-Sanz, 2011). For SOEP, I use actual working hours or, when missing, the sum of contractual working hours and of overtime (Kühhirt and Ludwig, 2012). Wages are then indexed at 2014 (2016 for the UK) prices and values below 1 or above 100 are trimmed, following standard practices in the literature (e.g. Kühhirt and Ludwig, 2012). Taking the natural logarithm of real wages then enables the interpretation of coefficients in terms of percentage effects on wage levels, since the log scale well approximates the percentage-point scale as long as coefficients lie in the $(-.25, .25)$ interval.

The model includes age and age squared ${ }^{2}$, to net out pure lifecycle effects, and period dummies $\phi_{t}{ }^{3}$. The variable Child ${ }_{i t}$ is a dummy that equals 0 prior to first childbirth and 1 in its aftermath. Pooling together all observations as if they belonged to different units, the OLS model cannot distinguish, however, person-year records belonging to the same person from person-year records belonging to a different one. Estimates of $\beta$ in Equation 1, therefore, simply contrast records in which the transition to fatherhood has occurred (Child ${ }_{i t}$ $=1)$ to records in which the transition has not occurred $\left(\right.$ Child $\left._{i t}=0\right)$. The latter group of observations includes both fathers-to-be prior to first childbirth and men belonging to the control group of childless men.

Differently, to focus on within-individual change, and thus on the transition to fatherhood, I contrast Equation 1 to the following fixed-effects (FE) specification:

$$
y_{i t}=\beta \text { Child }_{i t}+\gamma_{1} \text { Age }_{i t}+\gamma_{2} A g e_{i t}^{2}+\phi_{t}+\theta_{i}+\epsilon_{i t}
$$

The estimation of $\beta$ associated with Child $i t$ in Equation 2 rests only on within-unit variance, thanks to the inclusion of individual fixed effects $\theta_{i}$. It can be interpreted as the average one- 
off shift in wages men experience when becoming fathers. Further, individual fixed effects curb estimates of $\beta$ from time-invariant sources of selection into fatherhood. The role and direction of such type of selection can be assessed in two ways. First, I contrast OLS and FE estimates of the $\beta$ coefficient in both equations. Negative selection on time-invariant individual characteristics should be signalled by an increase in the magnitude of $\beta$ in the FE model; positive selection, vice versa, by a decrease. Second, I look at the correlation coefficient $r\left(\theta_{i}\right.$, Child $\left._{i t}\right)$, expressing the sign and magnitude of selection into fatherhood in terms of the correlation between wage-relevant time-constant unobservables $\theta_{i}$ and the variable for fatherhood, Child $d_{i t}$ (e.g. Gangl and Ziefle, 2009).

While the model in Equation 2 nets out time-invariant sources of selection, it still makes a number of assumptions. First, it assumes that the change in wage levels come fatherhood can be expressed as a one-off change, summarized by a single coefficient $\beta$. Research on male marital wage premiums and motherhood wage penalties alike has now well established that family events impact wages in a dynamic fashion (e.g. Korenman and Neumark, 1991; Dougherty, 2006; Loughran and Zissimopoulos, 2009; Kleven et al., 2018). In other words, one is better off modelling parenthood effects year-by-year after a child's birth, as short-, medium-, and long-run shifts in wage levels may differ as years go by since the event of interest. Further, Equation 2 assumes the absence of a pre-trend, i.e. that the wages of fathers do not grow prior to - and perhaps anticipating - fatherhood. Both assumptions are relaxed by deploying an event-study design (e.g. Kleven et al., 2018), adding lags and leads $k$ of Child $_{i t}$ as follows (see also, Imai and Kim, 2017):

$$
y_{i t}=\sum_{k=0}^{k=10} \beta_{k} \mathbb{1}\left(k=t-C h i l d^{i}\right)+\gamma_{1} A g e_{i t}+\gamma_{2} A g e_{i t}^{2}+\phi_{t}+\theta_{i}+\epsilon_{i t}
$$

With Child ${ }^{i}$, I now indicate the year in which the child's birth occurs for an individual $i$. Calendar time keeps being signalled by the subscript $t . \mathbb{1}(k=\ldots)$ is the indicator function 
whose argument can be either 1 or 0, i.e. a (set of) dummy variable(s). Equation 3 then includes event-time dummies $k$ for each year $t$ up to the fifth prior to first childbirth and up to the tenth after first childbirth ${ }^{4}$.

With Equation 3, I am thus able to capture the dynamic evolution of wages (if any) after fatherhood. Yet, prior to fatherhood, fathers-to-be and childless men could be on different wage growth paths. This would violate common assumptions underlying the FE estimator: namely. the strict exogeneity assumption for a treatment in fixed-effects estimation, such as Child $_{i t}$ in Equation 2, requires that outcomes evolve in parallel for controls and treated prior to the treatment (e.g. Wooldridge, 2010; Brüderl and Ludwig, 2015). In my case, childless men and fathers-to-be (prior to fatherhood onset) should experience similar wage growth. Hence, to compound evidence obtained via the FE estimators in Equations 2 and 3, one can ask if any effect of fatherhood on wages can be detected once any individual trend in wage growth is netted out (Ludwig and Brüderl, 2018; Kahn-Lang and Lang, 2018). A more restrictive specification of this kind could fully account for the chance that fathers-to-be and childless men may be on different wage-growth paths. It could permit wage growth to depend on any (time-invariant) individual characteristic, since each man in the sample would basically have his own wage slope.

A fixed-effects individual-slope (FEIS) model (e.g. Brüderl and Ludwig, 2015) is thus fitted in the following steps: first, one should estimate an OLS regression for each individual $i$, regressing log-wages $y_{i t}$ on a constant and a linear term for age; second, get the predicted values and subtract them from $y_{i t}$, thus obtaining wage values for each individual $i$ that are both de-meaned (constant term in step 1) and de-trended (quadratic for age in step 1); third, repeat step 1 for all independent variables to de-mean and de-trend them as well; finally, run an OLS on the transformed data ${ }^{5}$. A compact formulation of the model is as follows (Wooldridge, 2010: 377): 


$$
y_{i t}=\beta C h i l d_{i t}+\gamma_{2} A g e_{i t}^{2}+\phi_{t}+\mathbf{W}_{i t}^{\prime} \theta_{i}+\epsilon_{i t}
$$

With respect to the fixed-effects specification in Equation 2, I allow now for the individual fixed effects $\theta_{i}$ to interact with some observable variables, namely the linear term for age, contained in the vector $\mathbf{W}_{i t}^{\prime}$. I ran such FEIS estimation both using the single dummy variable Child $_{i t}$ and, separately, the event-study approach of Equation 3. Notably, since FEIS estimation is based on a OLS model for each single individual (step 1) including two parameters (the constant term plus a linear slope for age), at least three observations per person are needed, hence the aforementioned sample restriction (Ludwig and Brüderl, 2018).

\section{Main findings}

Pooling data from all the available waves, Figure 1 depicts average wage levels from age 20 onwards and separately for men who will eventually become fathers and for men who will not. Trends are similar in Germany and Britain. Wages at the mean grow at a slightly faster pace for fathers relative to non-fathers up until their late 20s/early 30s. After that, the wages of men who will remain childless stagnate, while men who did or will experience the transition to parenthood earn even higher wages than in their youth. Such a pattern could be consistent with the existence of a fatherhood wage bonus, as wage trajectories diverge right around the age of first-time fatherhood in both countries (McMunn et al., 2015; Struffolino et al., 2016). The picture cannot be conclusive, however, on whether men experience a wage premium come parenthood or some antecedent factors boost the wages of fathers-to-be. Turning to statistical models, OLS estimates in the first column of Table 1 and Table 2 reflect the patterns displayed in Figure 1. Fatherhood is associated with an average wage gain of about 14 percent in Germany and 17 percent in Britain. In terms of magnitude, these estimates are slightly higher than those highlighted for the US in previous studies (Lundberg 
and Rose, 2000; Hodges and Budig, 2010). Yet OLS regression pools all observations in the panel and does not distinguish records belonging to the same individual from records belonging to a different individual. As a result, OLS estimates in the first column of both tables simply contrast person-year records of men once they have become fathers with personyear records of men who are not (or not yet) fathers. I thus quantify the differential already shown in Figure 1, but cannot address the potential bias stemming from selection into fatherhood.

A step forward in this direction comes from FE estimates in the second column of Tables 1 and 2. Such estimates focus on within-individual variation and therefore can be interpreted as the one-off shift in wage levels brought about, on average, by the transition to fatherhood. Netting time-invariant differences between men by means of individual fixed effects, estimates are reduced. The shift in wages brought about by fatherhood stops at around 4.5 percent in Germany. For British men, differently, the fatherhood wage premium halts at around 2.6 percent $(p=.062)$. The decrease in size compared to OLS estimates is opposite to what previous studies have found for the US. Selection into fatherhood in both Germany and Britain seems to be positive, on average: high-earning men in both countries are more likely to become fathers. At the bottom of both tables, correlations $r\left(\theta_{i}, C_{h i l d}\right)$ further support this conclusion. For both countries, I found moderate and positive correlations between timeinvariant unobserved heterogeneity $\theta_{i}$ and my indicator variable for fatherhood. Unobserved, time-invariant factors relevant for wage determination are also positively correlated with the transition to fatherhood.

While netting out time-invariant heterogeneity between individuals substantially reduces the bonus, FE estimates could still be biased if the wages of men who eventually become fathers grow at a faster pace than those of their childless counterparts. In the third column of Tables 1 and 2, fixed-effects individual-slope (FEIS) estimates address this by letting the wage-age profile vary between men. Now, including individual slopes, I cannot reject the hypothesis 
that the effect fatherhood has on wages is actually nil for German men $(\beta=-0.006, p=$ .543). The same can be said for British men looking at FEIS estimates in Table 2 ( $\beta=$ $-0.004, p=.738)$. Hence, once the possibility of divergent individual wage trajectories is accounted for, the evidence does not support a causal story for the fatherhood wage bonus (as in Ludwig and Brüderl, 2018 for US men).

So far, I have assumed that fatherhood may bring about a one-off shift in men's wage levels. Such assumption could be unwarranted though. For example, men could increase their work effort or specialize in paid work particularly in the first years following a child's birth, often compensating for mothers' work interruptions and subsequent income loss in that period. As many applied and methodological contributions have shown (e.g. Korenman and Neumark, 1991; Borusyak and Jaravel, 2016), a simple dummy for "before-after" the event of childbirth will not help retrieving more complex, dynamic effects. Figure 2 thus displays estimates from an event-study approach, in which the wage response to fatherhood is singled out for each year after that of a child's birth - as per Equation 3. For German men, the figure supports the presence of a fatherhood wage bonus, especially in the short term. FE estimates in the first five years are all positive, statistically distinguishable from zero, and around the size previously assessed with the single-dummy approach ( $\approx 5$ percent). For British men, differently, wage bonuses of around 2 to 4 percent persist in the short term.

Yet, turning to FEIS estimates and thus accounting for idiosyncratic wage growth, the alleged premium shrinks further and I cannot reject the null anymore at conventional levels for both countries. For Germany, in particular, positive wage effects of around 1-2 percent are visible in years $0(p=.112), 1(p=.328)$, and $2(p=.062)$, while estimates turn negative in the following years. FEIS estimates for the UK are more noisy, possibly due to the smaller sample size, and similarly prompt to reach no conclusion on the presence of a fatherhood wage premium. Hence, even if the wage trajectories of fathers and non-fathers depicted in Figure 2 differ markedly in both countries, there is no strong evidence to conclude 
that fatherhood boosts men's wages in Germany and the UK. Rather, the apparent wage premium can be traced back, by and large, to positive selection both on the basis of wage levels (static) and on the basis of wage growth (dynamic). Already prior to their child's birth, fathers-to-be earn relatively higher wages and are on superior wage growth paths than their childless counterparts.

\subsection{Heterogeneous effects? Some exploratory analyses}

On balance, the evidence presented in the previous section cannot support the idea of a causal fatherhood wage premium. Regardless of the estimation method though, all my analyses have tested for the presence of a premium for all men, on average. Previous research, however, while often bypassing the selection concerns highlighted here, has already sought to establish that not all men gain equally from fatherhood. Heterogeneity in the fatherhood premium has been investigated, for example, over time (Petersen et al., 2014), along the earnings distribution (Cooke, 2014), or depending on men's skill level (Hodges and Budig, 2010; Cooke and Fuller, 2018), race (Hodges and Budig, 2010), and their ties to the partner (marriage, cohabitation, etc.) and offspring (biological, adopted, etc.) (Lundberg and Rose, 2000; Killewald, 2013). The methodological literature, in addition, has also recently clarified how the identification of a causal effect by means of fixed-effects estimation critically hinges upon the assumption that the effect of interest is homogeneous among units (Borusyak and Jaravel, 2016; Imai and Kim, 2017). Throughout the paper, in other words, I have assumed that any fatherhood wage bonus may benefit men equally and heterogeneity in the premium can be neglected, an assumption that could be unwarranted. Although beyond the scope of this paper, I present here exploratory analyses ${ }^{6}$ delving into whether the effect of fatherhood on wages may actually be heterogeneous, investigating stratification by $a$ ) birth cohort and b) skill level.

Cohort differences may be of particular interest considering the institutional background 
of the countries under examination here. With a focus on both culture and institutions, I have argued that the UK and Germany shifted away from a traditional male-breadwinner model in recent decades. Fatherhood wage premiums might thus be "a thing of the past". In Germany, for instance, men born prior to 1960 modestly increased working hours after the birth of a child (Pollmann-Schult and Reynolds, 2017) and, up until very recently, a very small share $(<3 \%)$ of new fathers went on parental leave (Bünning, 2015). In Figure 3, I repeat the analyses of Table 1 separately for the 1950-59, 1960-67, and 1968+ birth cohorts. OLS estimates suggest that fatherhood is associated with higher wages for men, especially for those belonging to the older cohorts. After the inclusion of individual fixed effects, estimates for all cohorts are substantially smaller; higher-earning men are thus more likely to become fathers in all cohorts considered. Net of time-invariant unobservables, fatherhood seemingly brings about wage boosts of around 7.1 percent for the 1950-59 cohort, 5.4 percent for the 1960-69 cohort, and 3.1 percent in the youngest cohort. Finally, in the FEIS specification, estimates further reduce and are no longer statistically distinguishable from zero also for men in the oldest cohort (in particular, $p=.277$ for the 3 percent boost in the 1950-59 cohort). Results for Britain in Figure 3 exhibit the same pattern across model specifications. In the FEIS specification, fatherhood brings about a wage gain of around 2 percent for the 1960-67 cohort $(p=.283)^{7}$ while the estimate for the younger cohort is actually negative $(-0.01, p$ $=.446)$.

I also look at heterogeneity by skill, defined in terms of level of education. Previous research for the US and Canada has yielded mixed evidence on whether low- or high-skill individual benefit more from fatherhood (Hodges and Budig, 2010; Cooke and Fuller, 2018). In Figure 4, I distinguish three levels of education building on the CASMIN classification: low-educated (lower-secondary education or less, CASMIN 1a to 2b), intermediate (upper-secondary education, CASMIN 2c), and highly-educated (tertiary, CASMIN 3a and 3b). For Germany, on the left, OLS estimates would suggest a U-shaped pattern, with fatherhood associated with 
higher wages particularly for low- and highly-educated men. Once again, FE estimates of the premium are much smaller than their OLS counterparts, suggesting that positive selection into fatherhood may be at play for German men of all education levels. Notably, FE and FEIS estimates remain positive only for low-educated and highly-educated individuals. FE estimates for men with upper-secondary education even turn negative. Premiums could not be detected for men of all education groups, looking at FE and FEIS estimates.

Differently for the UK, estimates derived by the naïve OLS estimator are quite comparable across education levels, although a U-shaped pattern emerges nonetheless. A smaller, and modest premium of around 5 percent is observed when deploying the FE estimator for men with low levels of education $(p=.036)$. Turning to FEIS estimates, once again, we can no longer detect wage premiums for each of the three skill groups.

\section{Discussion and conclusions}

In this study I ask whether men get a wage premium when becoming fathers in countries that have long supported male breadwinning, both culturally and via welfare and labour market institutions. I propose that selection into fatherhood may have been neglected. Observed premiums could be a statistical artifact if men who become fathers have a higher earning potential and experience steeper wage growth than men that will eventually remain childless. By deploying several model specifications that variously account for such selection dynamics, I cannot reject the null hypothesis of no effect of fatherhood on men's wages. Such inconclusive findings hold for the whole sample of men, as well as stratifying by men's birth cohort and skill level, in both the UK and Germany.

My findings stand in contrast with previous (US-based) longitudinal studies (Lundberg and Rose, 2000; Hodges and Budig, 2010; Killewald and Gough, 2013) in a twofold sense. First, pertaining to selection into fatherhood, I find that British and German men positively select into parenthood on the basis of time-invariant unobserved factors. Second, considering 
selection on such time-invariant unobserved factors and on prior wage growth, I cannot conclude that fatherhood sparks the wage attainment of men in the UK and Germany. As a consequence, highlighting the crucial role played by selection dynamics casts doubts on the credibility of estimates derived by cross-sectional data, lest they will account for selection into fatherhood as well. So far largely confined to the role of "unobservables", results in this study prompt further research on those features (personality, non-cognitive skills, beauty, etc., see e.g. Bowles et al., 2001) that may matter for both wage attainment and the transition to fatherhood, to be considered also in a comparative perspective.

Surely, the inability to reject the null in this study could reflect the fact that fatherhood indeed has a negligible (causal) effect on men's wages, but it may also stem from $a$ ) lack of statistical power, $b$ ) measurement error, and $c$ ) deficiencies in the study design. Sample sizes in this study are highly comparable to previous longitudinal studies on fatherhood and wages (e.g. Smith Koslowski, 2011; Killewald and Gough, 2013). Yet, if true effects are small or very small I may have failed to detect them due to lack of statistical power. Across both my main and sub-group analyses, I could detect wage premiums only when at least of a magnitude of around 4 percent. If even smaller premiums exist and could not be detected here, however, it is worth to question what their substantial significance would be, especially when contrasted, on the other hand, with the order of magnitude of motherhood wage penalties (e.g. Gangl and Ziefle, 2009; Harkness, 2016; Kleven et al., 2018; Cools et al., 2017).

Findings in this paper may also be invalidated by measurement errors. Measurement error could affect the computation of log hourly wages as well as the construction of the key independent variable operationalizing the transition to fatherhood. For the former, I relied on well-established practices in the literature (e.g. Gangl and Ziefle, 2009; Bryan and Sevilla-Sanz, 2011; Kühhirt and Ludwig, 2012) and I can only note that my conclusions on fatherhood and wages are in line with those of studies using perhaps more precise register data, albeit for different countries (Kleven et al., 2018; Cools et al., 2017). Further, 
using fertility history files has enabled me to detect the precise timing of the transition to fatherhood, a crucial requirement for the event-study part of the analyses presented here. For Germany, G-SOEP started collecting fertility history information on men only from 2000 onwards (Goebel, 2017). Respondents that dropped from the panel prior to that date are not included in the analysis. Nevertheless, replicating the analyses for Germany using fertility info from the core file ("number of children in the household") does not alter any of the conclusions on the impact of fatherhood on wages for German men (output available upon request).

Finally, while the study design of this paper has sought to curb estimates of the fatherhood bonus from multiple sources of selection bias, evidence from alternative causal designs should complement my findings. Examples of alternative designs could include quasi-experimental studies matching childless men and fathers on time-constant and, especially, time-varying confounders (e.g. Mincy et al., 2009 for the male marital wage premium), or approaches based on instrumenting the transition to parenthood (e.g. Cools et al., 2017; Kleven et al., 2018). Experimental studies, so far failing to detect a preference for fathers in terms of hiring chances in field settings (Correll et al., 2007; Bygren et al., 2017), could also complement the evidence of this study by investigating employers' wage offers to prospective male employees, depending on parental status. Additionally, while this study has focused on the transition to fatherhood and possible heterogeneities by cohort and skill, future research could deploy the same stringent tests to assess how men's wages respond to higher-order parities and across other social groupings. Parity- and group-specific mechanisms should of course motivate these analyses.

All in all, the evidence amassed in this study cannot support the idea of a causal wage premium for fathers in Germany and the UK. One consequence might be that, as much as gender wage gaps in the two countries are driven by the transition to parenthood, the penalty for mothers rather than the premium for fathers really drives the gap in labour 
markets. Absent wage boosts for fathers, the mommy penalty cannot be compensated for within the confines of the household alone. Evidence on men's wages in this paper indirectly calls for continued research on those policies that may mitigate the motherhood wage penalty and reduce gender economic inequalities more at large.

Notably, findings for the UK and Germany are in line with those of similar event-study designs for Scandinavian countries (for Denmark, Kleven et al., 2018; for Norway, Cools et al., 2017), countries that have a much longer tradition of support for men's role as carers and women's role as earners. As increasingly inclusive care policies are implemented in former male-breadwinner societies too, especially in the form of parental leaves, future research could evaluate their impact on men's labour market outcomes (e.g. for Scandinavia, Rege and Solli, 2013; Albrecht et al., 2015). Evidence in this study cannot support a causal story linking wages and fatherhood per se, after all. 


\section{Notes}

${ }^{1}$ Wage penalties for fathers taking leave may also stem from a re-orientation of effort from the market to the household (Rege and Solli, 2013). Yet, German fathers taking parental leave do not invest more time in childcare activities subsequently (Kluve and Tamm, 2013). Adverse signalling may therefore be a more suitable explanation for the wage losses German fathers, similar to their Swedish counterparts, could experience after taking parental leave.

${ }^{2}$ I experimented with different polynomial forms (quadratic, cubic, and quartic) and the full set of dummies for age, potential labour market experience, and (for SOEP only, due to data availability) actual labour market experience. Results hold regardless (output available upon request).

${ }^{3}$ I use 3-year dummies. In G-SOEP, interviews are carried out annually: when applying the withinindividual transformation in fixed-effects models, age and interview year thus increase of one unit each year creating collinearity between the two variables in the FE regression model. Grouping period dummies circumvents this issue. For consistency, I deploy 3-year dummies for the UK arm of the analysis as well, although BHPS interviews naturally span over multiple years.

${ }^{4}$ More precisely, the dummy for $k=10$ includes also all years after that point in time.

${ }^{5}$ All these steps are automated in the STATA routine xtfeis (Brüderl and Ludwig, 2015) which I deploy.

${ }^{6}$ Given the partitioning of the sample, I refrain from presenting the event-study part of my analyses on these separate groups due to the small cell size. Nonetheless, event-study results (available upon request), with both FE and FEIS specifications, give no indication of a fatherhood bonus across cohorts and skill levels in the UK and Germany.

${ }^{7}$ Since BHPS started in 1991, I do not report estimates for the 1950-59 cohort for UK since they would be based on relatively older men (32 or older) experiencing the transition to parenthood. 


\section{Tables and graphs}

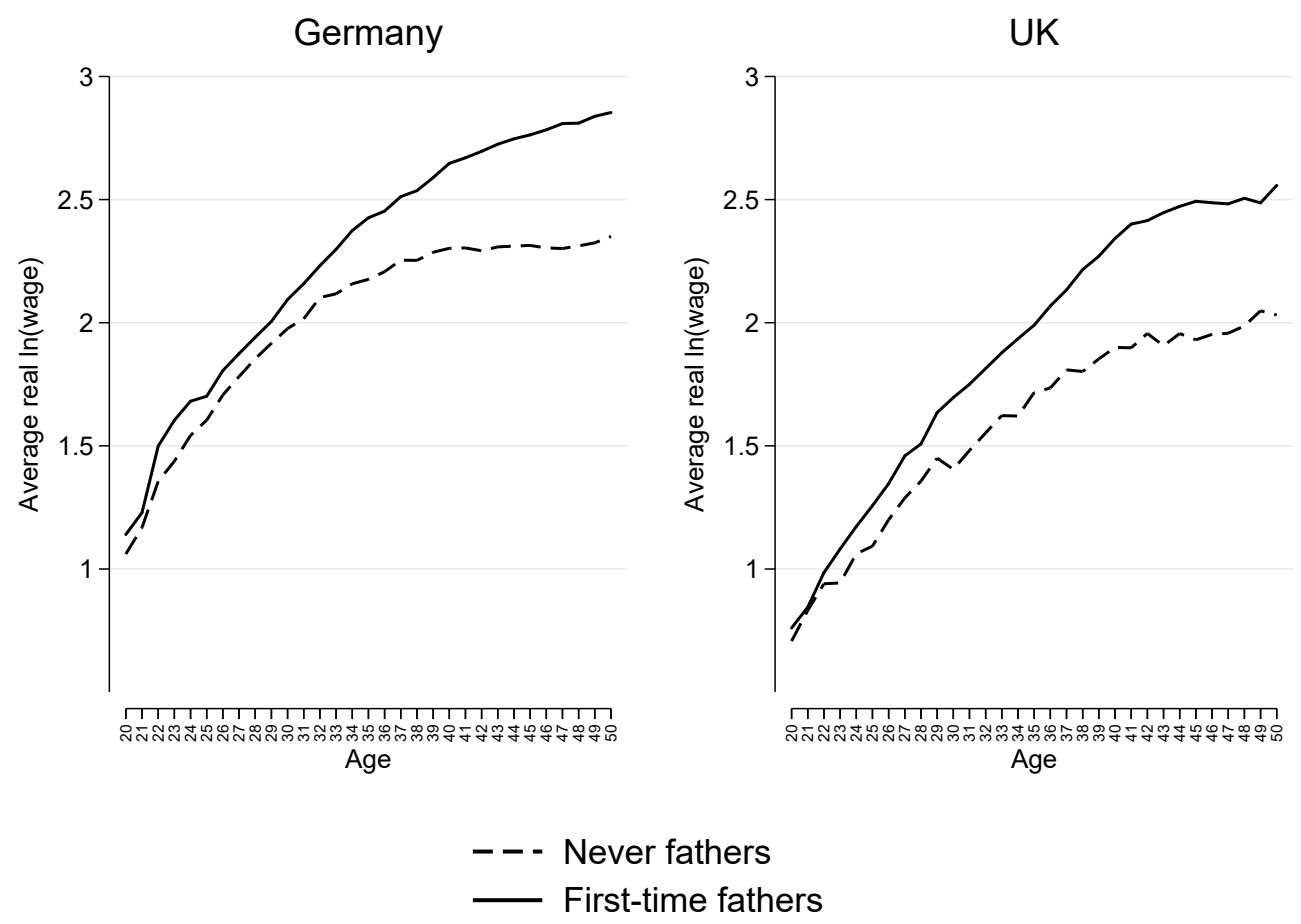

Figure 1: Average log hourly wages by respondent age, separately for childless men and fathers. Sources: G-SOEP 1984-2014, BHPS 1991-2016. 
Table 1: OLS, FE, and FEIS for the log of real hourly wages. German men (G-SOEP 1984-2014).

\begin{tabular}{lccc}
\hline & $(1)$ & $(2)$ & $(3)$ \\
& OLS & FE & FEIS \\
& $\beta(\mathrm{SE})$ & $\beta(\mathrm{SE})$ & $\beta$ (SE) \\
\hline First-time father $($ ref. childless) & $0.143^{* * *}$ & $0.045^{* * *}$ & -0.006 \\
& $(0.005)$ & $(0.011)$ & $(0.010)$ \\
\hline$r\left(\theta_{i}\right.$, Child $\left._{i t}\right)$ & & 0.233 & \\
\hline Number of individuals & 2,753 & 2,753 & 2,753 \\
Number of person-years & 35,297 & 35,297 & 35,297 \\
\hline
\end{tabular}

Notes: All models include period dummies and a quadratic for age. The latter is allowed to vary across individuals in the FEIS specification. Standard errors are clustered at the individual level.

${ }^{*} p \leq .05,{ }^{* *} p \leq .01,{ }^{* * *} p \leq .001$.

Table 2: OLS, FE, and FEIS for the log of real hourly wages. British men (BHPS 1991-2016).

\begin{tabular}{lccc}
\hline & $(1)$ & $(2)$ & $(3)$ \\
& OLS & FE & FEIS \\
& $\beta(\mathrm{SE})$ & $\beta(\mathrm{SE})$ & $\beta$ (SE) \\
\hline First-time father $($ ref. childless) & $0.170^{* * *}$ & 0.026 & -0.004 \\
& $(0.008)$ & $(0.014)$ & $(0.013)$ \\
\hline$r\left(\theta_{i}\right.$, Child $\left._{i t}\right)$ & & 0.227 & \\
\hline Number of individuals & 1,283 & 1,283 & 1,283 \\
Number of person-years & 15,730 & 15,730 & 15,730 \\
\hline
\end{tabular}

Notes: All models include period dummies and a quadratic for age. The latter is allowed to vary across individuals in the FEIS specification. Standard errors are clustered at the individual level.

${ }^{*} p \leq .05,{ }^{* *} p \leq .01,{ }^{* * *} p \leq .001$. 

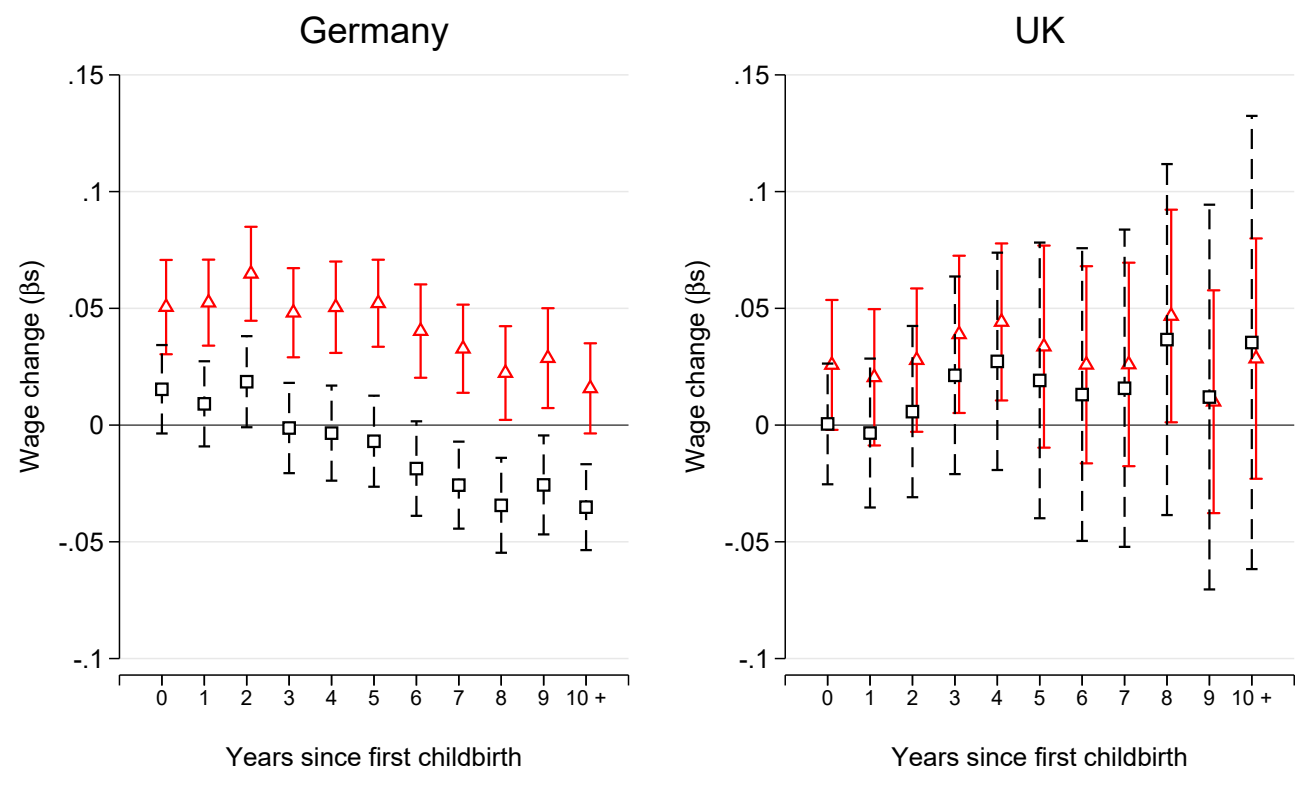

$\triangle$ FE
$\square$ FEIS

Figure 2: Point estimates and 95\% CI for the event study of fatherhood and wages. Fixedeffects (FE) estimates and fixed-effects individual-slope (FEIS) estimates on display. Models are detailed in the main text. Sources: G-SOEP 1984-2014, BHPS 1991-2016. 


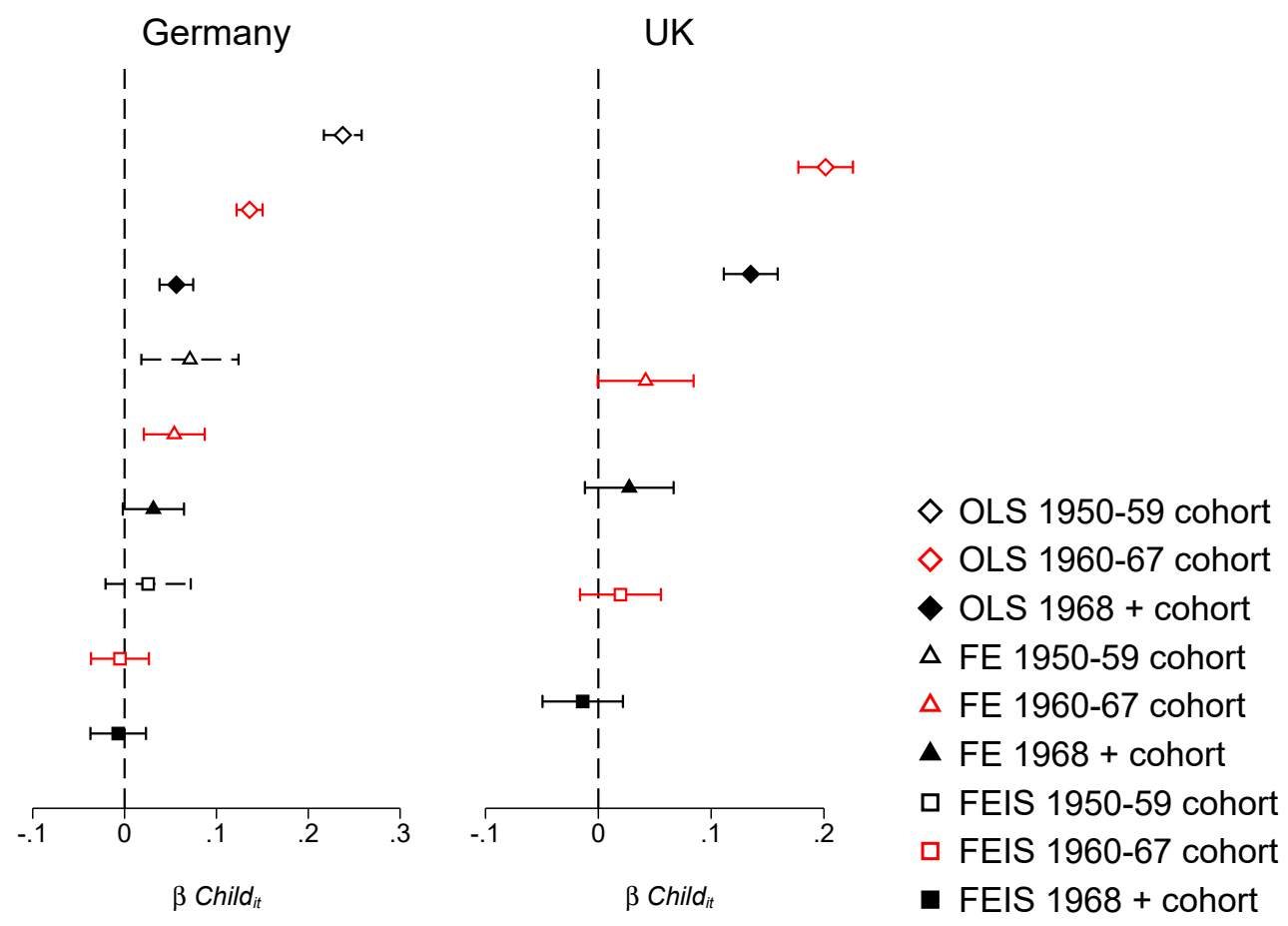

Figure 3: Point estimates and 95\% CI for the coefficient of first-time fatherhood on log wages. Separate models for different birth cohorts. Sources: G-SOEP 1984-2014, BHPS 1991-2016. 

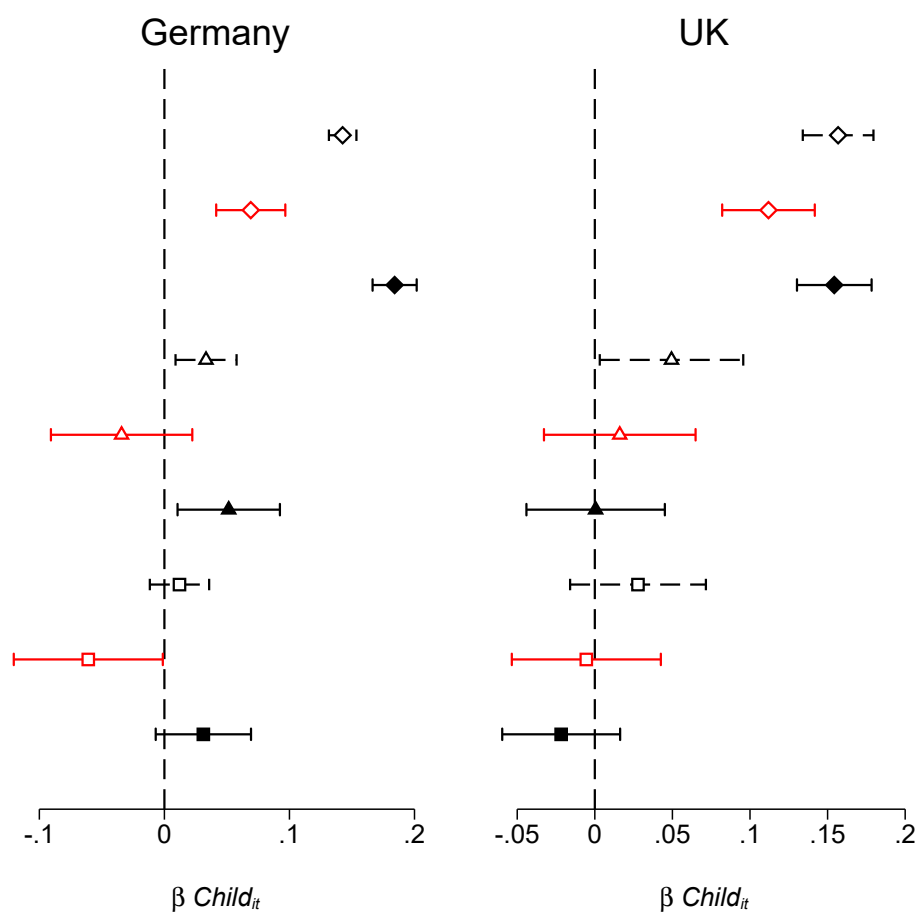
$\diamond$ OLS Low edu $\diamond$ OLS Middle edu $\checkmark$ OLS High edu
$\Delta$ FE Low edu
$\triangle$ FE Middle edu
\ FE High edu 口 FEIS Low edu 口 FEIS Middle edu - FEIS High edu

Figure 4: Point estimates and 95\% CI for the coefficient of first-time fatherhood on $\log$ wages. Separate models for men with different levels of education. Sources: G-SOEP 19842014, BHPS 1991-2016. 


\section{References}

Albrecht, J., P. S. Thoursie, and S. Vroman (2015). Parental leave and the glass ceiling in Sweden. Research in Labor Economics 41, 89-114.

Albrecht, J. W., P.-A. Edin, M. Sundström, and S. B. Vroman (1999). Career Interruptions and Subsequent Earnings: a Reexamination using Swedish Data. Journal of Human Resources 34 (2), 294-311.

Anxo, D., C. Fagan, I. Cebrian, and G. Moreno (2007). Patterns of labour market integration in Europe - a life course perspective on time policies. Socio-Economic Review 5(2), 233260.

Astone, N. M., J. K. Dariotis, F. L. Sonenstein, J. H. Pleck, and K. Hynes (2010). Men's work efforts and the transition to fatherhood. Journal of Family and Economic Issues 31(1), $3-13$.

Balbo, N., F. C. Billari, and M. Mills (2013). Fertility in advanced societies: A review of research. European Journal of Population/Revue européenne de Démographie 29(1), 1-38.

Becker, G. S. (1981). A Treatise on the Family. Cambridge, MA: Harvard University Press.

Bianchi, S. M. and M. A. Milkie (2010). Work and family research in the first decade of the 21st century. Journal of Marriage and Family 72(3), 705-725.

Bick, A. and N. Fuchs-Schündeln (2017). Taxation and Labour Supply of Married Couples across Countries: A Macroeconomic Analysis. The Review of Economic Studies 85 (3), $1543-1576$.

Blackburn, M. L., D. E. Bloom, and D. Neumark (1993). Fertility timing, wages, and human capital. Journal of Population Economics 6(1), 1-30.

Borusyak, K. and X. Jaravel (2016). Revisiting Event Study Designs. Working Paper, available at https://papers.ssrn.com/sol3/papers. cfm?abstract_id=2826228.

Bowles, S., H. Gintis, and M. Osborne (2001). The determinants of earnings: A behavioral approach. Journal of Economic Literature 39(4), 1137-1176. 
Brüderl, J. and V. Ludwig (2015). Fixed-effects panel regression. In H. Best and C. Wolf (Eds.), The Sage Handbook of Regression Analysis and Causal Inference, pp. 327-358. London: Sage.

Bryan, M. L. (2007). Workers, Workplaces and Working Hours. British Journal of Industrial Relations 45(4), 735-759.

Bryan, M. L. and A. Sevilla-Sanz (2011). Does housework lower wages? Evidence for Britain. Oxford Economic Papers 63(1), 187-210.

Buck, N. and S. McFall (2011). Understanding Society: design overview. Longitudinal and Life Course Studies 3(1), 5-17.

Bünning, M. (2015). What Happens after the 'Daddy Months'? Fathers' Involvement in Paid Work, Childcare, and Housework after Taking Parental Leave in Germany. European Sociological Review 31(6), 738-748.

Bünning, M. and M. Pollmann-Schult (2016). Family policies and fathers' working hours: cross-national differences in the paternal labour supply. Work, Employment and Society $30(2), 256-274$.

Bygren, M., A. Erlandsson, and M. Gähler (2017). Do Employers Prefer Fathers? Evidence from a Field Experiment Testing the Gender by Parenthood Interaction Effect on Callbacks to Job Applications. European Sociological Review 33(3), 337-348.

Cooke, L. P. (2014). Gendered parenthood penalties and premiums across the earnings distribution in Australia, the United Kingdom, and the United States. European Sociological Review 30(3), 360-372.

Cooke, L. P. and J. Baxter (2010). "Families" in International Context: Comparing Institutional Effects Across Western Societies. Journal of Marriage and Family 72(3), 516-536.

Cooke, L. P. and S. Fuller (2018). Class differences in establishment pathways to fatherhood wage premiums. Journal of Marriage and Family 80(3), 737-751.

Cools, S., S. Markussen, and M. Strøm (2017). Children and Careers: How Family Size Affects Parents' Labor Market Outcomes in the Long Run. Demography 54(5), 17731793. 
Correll, S. J., S. Benard, and I. Paik (2007). Getting a Job: Is There a Motherhood Penalty? American Journal of Sociology 112(5), 1297-1339.

Crompton, R. (1999). Restructuring Gender Relations and Employment: The Decline of the Male Breadwinner. Oxford: Oxford University Press.

Dariotis, J. K., J. H. Pleck, N. M. Astone, and F. L. Sonenstein (2011). Pathways of early fatherhood, marriage, and employment: a latent class growth analysis. Demography 48(2), 593.

Davis, S. N. and T. N. Greenstein (2009). Gender ideology: Components, predictors, and consequences. Annual Review of Sociology 35, 87-105.

Dechant, A. and A. Rinklake (2016). Anticipating motherhood and fatherhood - German couples' plans for childcare and paid work. In D. Grunow and M. Evertsson (Eds.), Couples' Transitions to Parenthood: Analysing Gender and Work in Europe. Edward Elgar Publishing.

Dotti Sani, G. M. (2015). Within-couple inequality in earnings and the relative motherhood penalty. A cross-national study of European countries. European Sociological Review $31(6), 667-682$.

Dougherty, C. (2006). The marriage earnings premium as a distributed fixed effect. Journal of Human Resources 41(2), 433-443.

Eggebeen, D. J. and C. Knoester (2001). Does fatherhood matter for men? Journal of Marriage and Family 63(2), 381-393.

Elwert, F. and C. Winship (2014). Endogenous selection bias: The problem of conditioning on a collider variable. Annual Review of Sociology 40,31-53.

Elzinga, C. H. and A. C. Liefbroer (2007). De-standardization of family-life trajectories of young adults: A cross-national comparison using sequence analysis. European Journal of Population/Revue européenne de Démographie 23(3-4), 225-250.

Fouarge, D., A. Manzoni, R. Muffels, and R. Luijkx (2010). Childbirth and cohort effects on mothers' labour supply: a comparative study using life history data for Germany, the Netherlands and Great Britain. Work, Employment \& Society 24(3), 487-507. 
Francesconi, M., H. Rainer, and W. Van Der Klaauw (2009). The Effects of In-Work Benefit Reform in Britain on Couples: Theory and Evidence. The Economic Journal 119(535), F66-F100.

Francesconi, M. and W. Van der Klaauw (2007). The socioeconomic consequences of "inwork" benefit reform for British lone mothers. Journal of Human Resources 42(1), 1-31.

Gangl, M. and A. Ziefle (2009). Motherhood, labor force behavior, and women's careers: An empirical assessment of the wage penalty for motherhood in Britain, Germany, and the United States. Demography 46(2), 341-369.

German Institute for Economic Research (DIW), Berlin (2016). Socio-Economic Panel (SOEP), data for years 1984-2014, version 31.1. SOEP, doi:10.5684/soep.v31.

Goebel, J. (2017). SOEP-Core v32 - Documentation on biography and life history data. SOEP Survey Papers, No. 418.

Grinza, E., F. Devicienti, M. Rossi, and D. Vannoni (2017). How Entry into Parenthood Shapes Gender Role Attitudes: New Evidence from Longitudinal UK Data. IZA DP No. 11088 .

Gustafsson, S. (1992). Separate taxation and married women's labor supply. Journal of Population Economics 5(1), 61-85.

Harkness, S. E. (2016). The Effect of Motherhood and Lone Motherhood on the Employment and Earnings of British Women: A Lifecycle Approach. European Sociological Review 32(6), 850-863.

Hodges, M. J. and M. J. Budig (2010). Who gets the daddy bonus? Organizational hegemonic masculinity and the impact of fatherhood on earnings. Gender 85 Society 24(6), 717-745.

Imai, K. and I. S. Kim (2017). When Should We Use Fixed Effects Regression Models for Causal Inference with Longitudinal Data? Working paper, https://imai.princeton. edu/research/files/FEmatch.pdf.

Kahn-Lang, A. and K. Lang (2018). The Promise and Pitfalls of Differences-in-Differences: Reflections on '16 and Pregnant'and Other Applications. NBER Working Paper 24857. 
Kalmijn, M., A. Loeve, and D. Manting (2007). Income dynamics in couples and the dissolution of marriage and cohabitation. Demography 44(1), 159-179.

Killewald, A. (2013). A reconsideration of the fatherhood premium: marriage, coresidence, biology, and fathers' wages. American Sociological Review 78(1), 96-116.

Killewald, A. and M. Gough (2013). Does specialization explain marriage penalties and premiums? American Sociological Review 78(3), 407-502.

Killewald, A. and I. Lundberg (2017). New Evidence against a Causal Marriage Wage Premium. Demography 54(3), forthcoming.

Kleven, H. J., C. Landais, and J. E. Sogaard (2018). Children and gender inequality: Evidence from Denmark. NBER Working Paper No. 24219.

Kluve, J. and M. Tamm (2013). Parental leave regulations, mothers' labor force attachment and fathers' childcare involvement: evidence from a natural experiment. Journal of Population Economics 26(3), 983-1005.

Knight, C. R. and M. C. Brinton (2017). One egalitarianism or several? Two decades of gender-role attitude change in Europe. American Journal of Sociology 122(5), 1485-1532.

Korenman, S. and D. Neumark (1991). Does marriage really make men more productive? Journal of Human Resources 26(2), 282-307.

Kreyenfeld, M. and D. Konietzka (2017). Childlessness in Europe: Contexts, causes, and consequences. Springer.

Kühhirt, M. (2012). Childbirth and the long-term division of labour within couples: how do substitution, bargaining power, and norms affect parents' time allocation in West Germany? European Sociological Review 28(5), 565-582.

Kühhirt, M. and V. Ludwig (2012). Domestic work and the wage penalty for motherhood in West Germany. Journal of Marriage and Family 74(1), 186-200.

Kuziemko, I., J. Pan, J. Shen, and E. Washington (2018). The Mommy Effect: Do Women Anticipate the Employment Effects of Motherhood? NBER Working Paper 24740. 
Lepinteur, A., S. Fleche, and N. Powdthavee (2016). My Baby Takes the Morning Train: Gender Identity, Fairness, and Relative Labor Supply Within Households. IZA Discussion Paper No. 10382.

Lewis, J. (1992). Gender and the development of welfare regimes. Journal of European Social Policy 2(3), 159-173.

Loughran, D. S. and J. M. Zissimopoulos (2009). Why wait? The effect of marriage and childbearing on the wages of men and women. Journal of Human Resources 44(2), 326349 .

Ludwig, V. and J. Brüderl (2018). Is There a Male Marital Wage Premium? New Evidence from the United States. American Sociological Review OnlineFirst, https://doi.org/10.1177/0003122418784909.

Lundberg, S. (2005). Men and islands: dealing with the family in empirical labor economics. Labour Economics 12(4), 591-612.

Lundberg, S. and E. Rose (2000). Parenthood and the earnings of married men and women. Labour Economics 7(6), 689-710.

McMunn, A., R. Lacey, D. Worts, P. McDonough, M. Stafford, C. Booker, M. Kumari, and A. Sacker (2015). De-standardization and gender convergence in work-family life courses in Great Britain: A multi-channel sequence analysis. Advances in Life Course Research 26, $60-75$.

Mincy, R., J. Hill, and M. Sinkewicz (2009). Marriage: Cause or mere indicator of future earnings growth? Journal of Policy Analysis and Management 28(3), 417-439.

O'Brien, M. and A. Koslowski (2017). International Review of Leave Policies and Research 2016. Available at: : http://www. leavenetwork. org/lp_and_r reports/.

O'Reilly, J., T. Nazio, and J. M. Roche (2014). Compromising conventions: attitudes of dissonance and indifference towards full-time maternal employment in Denmark, Spain, Poland and the UK. Work, employment and society 28(2), 168-188.

Paull, G. (2008). Children and women's hours of work. The Economic Journal 118(526), F8-F27. 
Percheski, C. and C. Wildeman (2008). Becoming a Dad: Employment Trajectories of Married, Cohabiting, and Nonresident Fathers. Social Science Quarterly 89(2), 482-501.

Petersen, T., A. M. Penner, and G. Høgsnes (2011). The male marital wage premium: Sorting vs. differential pay. Industrial \&3 Labor Relations Review 64 (2), 283-304.

Petersen, T., A. M. Penner, and G. Høgsnes (2014). From Motherhood Penalties to Husband Premia: The New Challenge for Gender Equality and Family Policy, Lessons from Norway. American Journal of Sociology 119(5), 1434-1472.

Phelps, E. S. (1972). The Statistical Theory of Racism and Sexism. American Economic Review 62(4), 659-661.

Pollmann-Schult, M. and J. Reynolds (2017). The Work and Wishes of Fathers: Actual and Preferred Work Hours among German Fathers. European Sociological Review 33(6), 823-838.

Ponthieux, S. and D. Meurs (2015). Gender Inequality. In A. B. Atkinson and F. Bourdignon (Eds.), Handbook of Income Distribution. Volume 2A. North Holland: Elsevier.

Pronzato, C. (2011). British Household Panel Survey Consolidated Marital, Cohabitation and Fertility Histories, 1991-2009. 3rd Edition. University of Essex: Institute for Social and Economic Research. UK Data Service. SN: 5629, http://doi.org/10.5255/ UKDA-SN-5629-1.

Rege, M. and I. F. Solli (2013). The impact of paternity leave on fathers' future earnings. Demography 50(6), 2255-2277.

Schober, P. S. (2013). The parenthood effect on gender inequality: Explaining the change in paid and domestic work when British couples become parents. European Sociological Review 29(1), 74-85.

Smith Koslowski, A. (2011). Working Fathers in Europe: Earning and Caring. European Sociological Review 27(2), 230-245.

Struffolino, E., M. Studer, and A. E. Fasang (2016). Gender, education, and family life courses in East and West Germany: Insights from new sequence analysis techniques. Advances in Life Course Research 29, 66-79. 
Taylor, M. F., J. Brice, N. Buck, and E. Prentice-Lane (2010). British Household Panel Survey: User Manual Volume A. Colchester: University of Essex.

Townsend, N. W. (2002). The package deal: Marriage, Work and Fatherhood in Men's Lives. Philadelphia: Temple.

Trappe, H., M. Pollmann-Schult, and C. Schmitt (2015). The rise and decline of the male breadwinner model: institutional underpinnings and future expectations. European Sociological Review 31(2), 230-242.

Trimarchi, A. and J. Van Bavel (2017). Education and the transition to fatherhood: The role of selection into union. Demography 54(1), 119-144.

University of Essex, Institute for Social and Economic Research (2018). Understanding Society: Waves 1-7, 2009-2016 and Harmonised BHPS: Waves 1-18, 1991-2009. 10th Edition. UK Data Service SN: 6614, http://doi.org/10.5255/UKDA--SN--6614--11.

Vargha, L., R. I. Gál, and M. O. Crosby-Nagy (2017). Household production and consumption over the life cycle: National Time Transfer Accounts in 14 European countries. Demographic Research 36, 905-944.

Wagner, G. G., J. R. Frick, J. Schupp, et al. (2007). The German Socio-Economic Panel Study (SOEP)-Scope, Evolution and Enhancements. Schmollers Jahrbuch: Journal of Applied Social Science Studies/Zeitschrift für Wirtschafts-und Sozialwissenschaften 127(1), 139-169.

Wooldridge, J. M. (2010). Econometric Analysis of Cross Section and Panel Data. MIT press. 